\title{
The Effect of Agglomeration Economy of City Group on Employment: Evidence from Ten City Groups in China
}

\author{
Qiuyang Liu, Yinxia Mi \\ Institute of Industrial Economics, Jinan University, Guangzhou, China \\ Email: qiuyang212@163.com
}

How to cite this paper: Liu, Q.Y. and Mi, Y.X. (2017) The Effect of Agglomeration Economy of City Group on Employment: Evidence from Ten City Groups in China. Modern Economy, 8, 643-654. https://doi.org/10.4236/me.2017.85046

Received: March 13, 2017

Accepted: May 9, 2017

Published: May 12, 2017

Copyright ( $\odot 2017$ by authors and Scientific Research Publishing Inc. This work is licensed under the Creative Commons Attribution International License (CC BY 4.0).

http://creativecommons.org/licenses/by/4.0/

\begin{abstract}
With the manner of treating ten city groups in China as the space unit, the current research analyzes the micro data of Chinese industrial enterprises during the period of 1998-2007 and investigates the effects of agglomeration economy of city group on the employment in manufacturing industry by using the fixed model. Specifically, results show that, both the city group economies of scale and city group economies of scope, referring as the two types of agglomeration economy of the city group, could significantly predict employment.
\end{abstract}

\section{Keywords}

City Group, Agglomeration Economy, Employment

\section{Introduction}

The role of city groups has become increasingly prominent, whether there are a number of the city groups with strong economic strength determines whether a country can occupy a favorable position in the international competition pattern. Specifically, the Chinese government has provided favorable policy support for the orderly development of city groups. For instance, "12th Five-Year" planning has proposed the construction of the city group with large radiation influence, to promote the coordinated development of large and medium cities as well as small towns. Additionally, National New Urbanization Plan (2014-2020) proposes to take the city group as the main form of promoting new urbanization.

City groups is clearly defined that the cities with a considerable number of different nature, type and scale depend on certain natural conditions in a specific 
geographical range, take one or two mega cities or super cities as the core of the regional economy, gain the help of modern transportation, the accessibility of integrated transportation network, and the highly developed information network, and jointly constitute a relatively complete collection of cities (Yao, 2001; Zhang and Li, 2014) [1] [2]. Reflection of this kind of agglomeration economy in the regional scale is the city group economy (Li and Miao, 2010) [3]. Obviously, the city group economy includes both the agglomeration economies based on the "place" and "regional" city group (Ding, 2010) [4]. As we all know, employment is the foundation of people's livelihood. Thus, whether the city group economy brought by the agglomeration of industries at the regional level can affect employment?

With the transferring of a large number of rural labors from the middle and west areas to the developed cities, a number of mega cities have emerged, the rapid expansion of the population makes the poor infrastructure, traffic congestion, housing shortage, structural unemployment and other social contradictions increasingly apparent, namely the so-called "urban disease". In order to alleviate this situation, the government put forward the "western development", "the rise of central China" and other strategies to encourage the transfer of labor and enterprises to the middle and western areas. As for its effectiveness, Fan and $\mathrm{Li}$ (2011) [5] found that the manufacturing industry began to spread from the southeastern coastal areas to the north coast and the central region, with the year of 2004 as a turning point. So, whether the promotion of the development of city group in middle and western city groups can promote employment in middle and western cities and realize the situ urbanization of the masses in the middle and west areas?

In light of solving the above questions, the current paper samples ten city groups in China, and investigates the effect of city group economy on employment by using the data of 128 prefecture-level cities contained.

\section{Literature Review}

Weber first proposed the term of "agglomeration economy" (Weber, 1909) [6], subsequently it has become an important tool for the interpretation of industrial agglomeration. Since 1990s, there have been a large number of literatures on the relationship between agglomeration economy and employment growth, but there is no consistent finding. Glaeser et al. (1992) [7] based on the employment data of 6 industries in 170 cities of the United States during 1956-1987, found that the local urbanization economy will promote the employment growth, while the local specialization economy has the opposite influence. Henderson et al. (1995) [8] further empirical analyzed the influencing factors of the employment growth of 224 metropolitan statistical areas in 1970-1987. They demonstrated that, for the traditional industries, the specialization economy has a significantly positive impact on the employment, but urbanization economy has no significantly impact, while in the high-tech industry, the urbanization economy had a positive impact on employment. Further, Bradley and Gans (1998) [9], Cainelli 
and Leoncini (1999) [10], Combes (2000) [11], Dekle (2002) [12], Blien and Suedekum (2005) [13], Van Soest et al. (2006) [14] based on different countries and found that the local specialization economy had a negative impact on employment growth, while the effect of urbanization economy on employment was inconsistent. Cingano and Schivardi (2004) [15] have suggested that when the crowding influence of the labor force prevails, the specialization economy will promote productivity, rather than promote employment growth.

In view of the limitations of data availability, many studies (Blanchard et al., 1992; Cainelli and Leoncini, 1999; Bonaccorsi et al., 2006) [10] [16] [17] examine the role of agglomeration economy in larger spatial ranges, such as provinces or regions. However, the concept of agglomeration economy has its own obvious composition characteristics of the small regional industry, which is more suitable for studying in the region of a lower level. If the selected space is too large, it will lead that the localization economy and urbanization indexes measuring industrial externalities can not reflect the objective facts, and lead to a bias in the results (Fan, 2011) [5]. In addition to the scale selection of geographic space, the difference of measuring indexes, sample selection, industrial properties and time range selection will lead to the dispute of research results (Chen et al., 2006; Beaudry and Schiffauerova, 2009) [18] [19].

The aforementioned studies, however, mainly focus on the scope of traditional agglomeration economy. Some scholars have questioned the interpretation ability of the traditional localization economy and urbanization economy, McCann and Fingleton (1996) [20] believed that the definition of neoclassical economic agglomeration does not reflect the costs that various enterprises want to use, and the agglomeration economy should be divided into neighborhood agglomeration economy, element agglomeration economy, coordination agglomeration economy and market economy agglomeration. Xiong (1997) [21] pointed out that, localization economy and urbanization economy in regional level, there should be economies of scale higher than the city, namely the national agglomeration economy. On this basis, Li and Miao (2010) [3] put forward the concept of "city group economy", suggesting that the city group economy is a new type of agglomeration economy that is different from the localization economy and urbanization economy. Ding (2010) [4] argues that city group economy can be divided into city group economies of scale and city group economies of scope. However, it still lacks the empirical research on the influence of agglomeration economy of the regional level of city group on employment.

Most of the domestic researches on agglomeration economy is based on the data of the macroscopic provincial level, and a small number of selected research levels have reached the level of the city, and mainly focus on the development of agglomeration economy and industry development (Batisse, 2002; Chen et al., 2006; Bo, 2007; Li and Song, 2008, He and Pan, 2009) [18] [22] [23] [24] [25], enterprise location choice (Liu and Zhang, 2010; Chen et al., 2011; Zhou et al., 2015) [26] [27] [28], and labor productivity (Zhang et al., 2007; Shi and Liu, 
2008; He, 2011; Fan et al., 2014) [29] [30] [31] [32], but the employment influences of agglomeration economies are generally ignored.

However, provincial administrative territory of China is too large, and provincial economy is in a highly unbalanced state; agglomeration economy index constructed based on the provincial data are very likely to lead to variable measurement errors. If taking the prefecture-level city as a geographical space unit, although the selected agglomeration level is relatively small, it ignores the spatial correlation and industrial relevance between cities, and neighborhood effect between different cities in the city groups and the benefit brought by distribution and cooperation effect. While in taking the city group as a regional research level, the geographical unit will not be too large, and the externalities brought by the economic linkages between the cities can be taken into consideration. Therefore, this paper selects ten city groups with the highest degree of development in China, totals up the micro enterprise data to obtain the employment data of 128 prefecture-level cities, and adopts the method of Fan et al., (2014) [32], construct city agglomeration economy index, so as to inspect the effect of city agglomeration economy on manufacturing employment.

\section{Econometric Model Setting and Variable Selection}

\subsection{Empirical Model Setting}

In order to estimate the impact of agglomeration economy on employment, this paper constructs the following linear econometric model:

$$
\begin{aligned}
& \ln \text { labor }_{i j k t}=\beta_{0}+\beta_{1} c s q L E_{i k t}+\beta_{2} c s q U E_{i k t}+\beta_{3} c i t y L E_{i j k t}+\beta_{4} c i t y U E_{i j k t} \\
& +\beta_{5} \ln D A C_{i j t}^{i n t r a}+\beta_{6} \ln D A C_{i j t}^{i n t e r}+\beta_{7} \ln \text { awage }_{i j k t}+\beta_{8} \ln \operatorname{acap}_{i j k t} \\
& +\beta_{9} \ln \text { denpopu }_{i j t}+\beta_{10} \ln g d p_{i j t}+u_{t}+\varepsilon_{i j k t}
\end{aligned}
$$

For Equation (1), the explained variable labor $_{i j k t}$ is the employment figure of industry $k$ in city $j$ of city group $i$ at moment $t, c s q L E_{i k t}$ and $c s q U E_{i k t}$ are respectively the city group economies of scale and city group economies of scope faced by industry $k$ of city group $i$ at moment $t, c_{i t y L} E_{i j k t}$ and city $U E_{i j k t}$ are respectively the localization economy and urbanization economy faced by industry $k$ in city $j$ of city group $i$ at moment $t, D A C_{i j t}^{\text {intra }}$ and $D A C_{i j t}^{\text {inter }}$ are respectively the intra-region demand accessibility and the inter-region demand accessibility of city $j$ in city group $i$ at moment $t$, awage $_{i j k t}$ is the average wage of industry $k$ in city $j$ of city group $i$ at moment $t$, denpopu $u_{i j t}$ is urban population density of city $j$ in city group $i$ at moment $t, g d p_{i j t}$ is the GDP of city $j$ in city group $i$ at moment $t, u_{t}$ is the time dummy variable, $\varepsilon_{i j k t}$ is a random disturbance term. In the following chapter, more explanations about the variables are given.

\subsection{Data}

In this paper, the concept of "urban agglomeration" is actually a kind of narrow sense of urban agglomeration, on the meaning is closer to the definition of Yao (2001) [1]. Yao believed that the city group is that the cities with a considerable 
number of different nature, type and scale depend on certain natural conditions in a specific geographical range, take one or two mega cities or super cities as the core of the regional economy, gain the help of modern transportation, the accessibility of integrated transportation network, and the highly developed information network, have the internal relationship between the individual cities happening or developed, and jointly constitute a relatively complete collection of cities.

According to Xiao and Yuan (2007) [33], this paper samples ten city groups (such as Beijing-Tianjin-Hebei Region) with the highest degree of development in China, uses the panel data of 1998-2007. The definitions of ten city groups are as follows (Table 1).

The sample data used in this paper mainly come from two data sets. The first data set is the database of Chinese industrial enterprises during 1998-2007. This paper focused on manufacturing enterprises. Counted by the two-digit industry code, the manufacturing industry of the data set covers 30 industries after 2003, corresponding to code 13 - 43 (without 38) in the classification and code of national economy industry (GB/T4754-2002).

Table 1. Definitions of ten city groups and the cities contained.

\begin{tabular}{|c|c|}
\hline City group & Cities contained \\
\hline $\begin{array}{l}\text { Beijing-Tianjin-Hebei city } \\
\text { group }\end{array}$ & $\begin{array}{c}\text { Beijing, Tianjin, Shijiazhuang, Tangshan, Qinhuangdao, Baoding, } \\
\text { Zhangjiakou, Chengde, Cangzhou, and Langfang }\end{array}$ \\
\hline $\begin{array}{l}\text { City group in the } \\
\text { central-southern } \\
\text { of Liaoning }\end{array}$ & $\begin{array}{c}\text { Shenyang, Dalian, Anshan, Fushun, Benxi, Dandong, Yingkou, } \\
\text { Liaoyang, Panjin, and Tieling }\end{array}$ \\
\hline $\begin{array}{l}\text { City group of } \\
\text { Yangtze River Delta }\end{array}$ & $\begin{array}{c}\text { Shanghai, Nanjing, Changzhou, Suzhou, Nantong, Yangzhou, } \\
\text { Zhenjiang, Hangzhou, Wuxi, Ningbo, Jiaxing, Huzhou, } \\
\text { Shaoxing, Zhoushan, and Taizhou }\end{array}$ \\
\hline $\begin{array}{l}\text { City group of Shandong } \\
\text { Peninsula }\end{array}$ & $\begin{array}{c}\text { Jinan, Qingdao, Zibo, Dongying, Yantai, Weifang, } \\
\text { Weihai, and Rizhao }\end{array}$ \\
\hline $\begin{array}{l}\text { City group of } \\
\text { Central Henan }\end{array}$ & $\begin{array}{l}\text { Zhengzhou, Kaifeng, Luoyang, Pingdingshan, } \\
\text { Xinxiang, Jiaozuo, Xuchang, Luohe, and Jiyuan }\end{array}$ \\
\hline $\begin{array}{l}\text { City group in the west coast } \\
\text { of the Taiwan Straits }\end{array}$ & $\begin{array}{c}\text { Fuzhou, Xiamen, Putian, Sanming, Quanzhou, Zhangzhou, } \\
\text { Nanping, Ningde, Longyan, Yingtan, Ganzhou, Shangrao, } \\
\text { Fuzhou, Wenzhou, Quzhou, Lishui, } \\
\text { Shantou, Meizhou, Chaozhou, Jieyang }\end{array}$ \\
\hline $\begin{array}{l}\text { City group in middle } \\
\text { reaches of Yangtze River }\end{array}$ & $\begin{array}{l}\text { Wuhan, Huangshi, Yichang, Xiangfan, Ezhou, Jingmen, Xiaogan, } \\
\text { Jingzhou, Huanggang, Xianning, Changsha, Zhuzhou, Xiangtan, } \\
\text { Hengyang, Yueyang, Changde, Yiyang, Loudi, Nanchang, } \\
\text { Jingdezhen, Pingxiang, Jiujiang, Xinyu, } \\
\text { Yingtan, Yichun, Shangrao, Ji'an, Fuzhou }\end{array}$ \\
\hline $\begin{array}{l}\text { City group of the Pearl } \\
\text { River Delta }\end{array}$ & $\begin{array}{l}\text { Guangzhou, Shenzhen, Zhuhai, Foshan, Jiangmen, } \\
\text { Zhaoqing, Huizhou, Dongguan and Zhongshan }\end{array}$ \\
\hline $\begin{array}{l}\text { City group in Sichuan and } \\
\text { Chongqing region }\end{array}$ & $\begin{array}{c}\text { Chongqing, Chengdu, Zigong, Luzhou, Deyang, Mianyang, } \\
\text { Suining, Ziyang, Meishan, Nanchong, Yibin, Ya'an, } \\
\text { Guang'an, Neijiang and Leshan }\end{array}$ \\
\hline $\begin{array}{l}\text { City group in the central } \\
\text { Shaanxi plain }\end{array}$ & Xi'an, Tongchuan, Baoji, Xianyang, Weinan and Shangluo \\
\hline
\end{tabular}


The second data set is from the China City Statistical Yearbook. Based on the economic, demographic and geographic information of cities, this paper constructs the explanatory variables, such as the population density of the urban characteristics in the regression model. The relevant data were adjusted with 1998 as the base year. In addition, this paper also uses Google map to get the highway mileage and travel time, so as to build up the accessibility index.

\subsection{Variables}

- Agglomeration economy of city group

1) City group economies of scale

First, the city group economies of scale means the "specialization economy" on the region scale, referring to the agglomeration of enterprises belonging to the same industry in the city groups, so that the externality can be brought by the continuous expansion of scale for certain industry inside the city group (Li and Miao, 2010; Fan, 2014) [3] [32]. The specific calculation formula as:

$$
\operatorname{csqLE}_{j k t}=\frac{\text { labor }_{j k t} / \text { labor }_{j t}}{\text { labor }_{k t} / \text { labor }_{t}}
$$

In the Equation (2), $c s q L E_{j k t}$ refers to the city group economies of scale, the larger the value is, such that the higher the specialization degree of industry $k$ in city group $j$ is. labor $_{j k t}$ refers to the employment figure of industry $k$ in city group

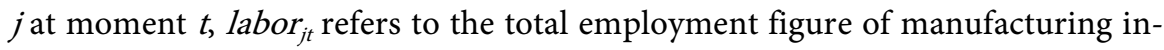
dustry in city group $j$ at moment $t$, labor $_{k t}$ refers to the total employment figure of industry $k$ at moment $t$ in the range of the whole country, while labor $_{t}$ refers to the total employment figure at moment $t$ in the range of the whole country.

2) City group economies of scope

Secondly, the city group economy of scope means the "diversification economy" in the regional level, referring to the agglomeration of enterprises belonging to the different and irrelevant industries in the city groups. The relative index is with the specific calculation formula as:

$$
\operatorname{csqUE}_{j k t}=\left(\sum_{k^{\prime}}\left|r l_{j k t}-r l_{k t}\right|\right)^{-1}, r l_{j k t}=\frac{\text { labor }_{j k t}}{\text { labor }_{j t}}, r l_{k t}=\frac{\text { labor }_{k t}}{\text { labor }_{t}}
$$

In the Equation (3), $c s q U E_{j k t}$ refers to the city group economies of scope, $k$ refers to the other industries outside industry $k, r l_{j k t}$ refers to the proportion of the employment figure of industry $k$ in city group $j$ at moment $t$ in the employment figure of city group $j$ at the same period, $r l_{k t}$ refers to the proportion of the employment figure of industry $k$ at moment $t$ in the employment figure of the national manufacturing industry.

- Urban agglomeration economy

Urban agglomeration economy in local scale is one of the main factors affecting employment. In this paper, the relative index is used to construct the localization economy $(L E)$ and the urbanization economy $(U E)$. The specific calculation methods are shown in formula (1) and formula (2).

- Other control variables 
The central city of the city group plays a role of growth pole in the economic development of all prefecture-level cities in the city group (Jin et al., 2006; Zhang, 2013; Zhou and Yu, 2015) [28] [34] [35], so it is taken as the potential market of all prefecture-level cities, and the total amount of wages in the central city is used to measure the demand scale. The formula for calculating the intra-region accessibility is:

$$
D A C_{j}^{\text {intra }}=\frac{\text { wage }_{j c}}{t_{j, j c}}
$$

In the Equation (4), $j c$ refers to the central city of city group that the city $j$ belongs to, wage $_{j c}$ refers to the wages of the central city, while the $\left(t_{j, j}\right)$ represents the road travel time between the central city $j c$ and the city $j$. For city group with more than one central city, the average value shall be counted.

In addition, city group is usually represented as a "center-periphery" spatial distribution, as the growth pole and core leader of the economic development of the city group, the central city is closely linked with the economy of each city, to form a good leading role. The formula for calculating the inter-region demand accessibility:

$$
D A C_{j}^{\text {inter }}=\sum_{i=1}^{m} \frac{\text { wage }_{i c}}{t_{j, i c}}
$$

In the Equation (5), $i$ represents the code of the city group neighboring to the city group where the city $j$ is located, $m$ represents that there are $m$ neighboring city groups. Definitions of wage $_{i c}$ and $\left(t_{j, i c}\right)$ are similar to that of the intra-region demand accessibility. Neighboring city groups are divided in accordance with the distance.

In addition, this paper also introduces the average capital per labor (acap) to describe the capital intensive of enterprise, the average wage (awage) to describe the labor cost of enterprise, the density of population (denpopu) to describe the city population scale, and the gross domestic product ( $g d p$ ) to describe the local economies of scale. In order to linearize the sequence and reduce the influence of the heteroscedasticity, we conduct the logarithm form to all the variables other than the agglomeration economy indexes.

\section{Estimation Results and Analysis}

After adding control variables, 3 regression models are obtained by using the methods of agglomeration economy of city group and urban agglomeration economy. The basic regression results are shown in Table 2.

The final regression results adopted are shown in model (3) at the column 4 in Table 2. First of all, coefficients for the city group economies of scale and the city group economies of scope are all positive, with the significance level tested for $1 \%$. Specifically, the coefficient of city group economies of scope is 0.175 , which shows that the agglomeration of regional "localization economy" of the same industry in the city group has a significant positive influence on the employment figure within the industry. This positive influence may come from the 
Table 2. Estimation results.

\begin{tabular}{|c|c|c|c|}
\hline \multirow{2}{*}{ Dependentvariable: $\ln l a b o r$} & \multicolumn{3}{|c|}{ Fixed effect } \\
\hline & Model (1) & Model (2) & Model (3) \\
\hline \multirow{2}{*}{$\operatorname{csq} L E$} & $0.277^{\star * *}$ & $-0.036^{\star *}$ & $0.175^{\star * *}$ \\
\hline & $(17.652)$ & $(-2.387)$ & $(10.527)$ \\
\hline \multirow{2}{*}{$\operatorname{csq} U E$} & $0.296^{* * *}$ & $0.218^{* * *}$ & $0.280^{* * *}$ \\
\hline & $(24.070)$ & $(18.287)$ & $(18.402)$ \\
\hline \multirow{2}{*}{$\ln D A C^{\text {intra }}$} & $0.156^{\star * *}$ & $0.136^{\star * *}$ & $0.108^{\star * *}$ \\
\hline & $(7.209)$ & $(6.908)$ & $(5.150)$ \\
\hline \multirow{2}{*}{$\ln D A C^{\text {inter }}$} & $0.161^{\star \star *}$ & $0.155^{\star * \star}$ & $0.135^{\star * *}$ \\
\hline & $(5.547)$ & $(5.877)$ & $(4.854)$ \\
\hline \multirow{2}{*}{ lnawage } & $-0.072^{\star * *}$ & $-0.063^{\star \star \star}$ & $-0.072^{\star * *}$ \\
\hline & $(-6.568)$ & $(-6.351)$ & $(-6.391)$ \\
\hline \multirow{2}{*}{$\ln a c a p$} & $-0.065^{\star * *}$ & $-0.052^{* * *}$ & $-0.053^{* * *}$ \\
\hline & $(-10.948)$ & $(-9.654)$ & $(-8.708)$ \\
\hline \multirow{2}{*}{$\ln$ denpopu } & $-0.051^{\star * *}$ & $-0.048^{\star * *}$ & $-0.096^{\star * *}$ \\
\hline & $(-3.909)$ & $(-4.061)$ & $(-6.859)$ \\
\hline \multirow{2}{*}{$\ln g d p$} & $0.046^{* * *}$ & $0.060^{* * *}$ & $0.213^{* * *}$ \\
\hline & $(5.633)$ & $(8.086)$ & $(9.853)$ \\
\hline \multirow{2}{*}{ cityLE } & & $0.313^{* * *}$ & \\
\hline & & $(72.528)$ & \\
\hline \multirow{2}{*}{ cityUE } & & $0.408^{\star * *}$ & \\
\hline & & $(19.949)$ & \\
\hline \multirow{2}{*}{ cityLE_L } & & & $0.174^{* * *}$ \\
\hline & & & $(35.180)$ \\
\hline \multirow{2}{*}{ cityUE_L } & & & $0.251^{\star * *}$ \\
\hline & & & (10.907) \\
\hline Time fixed effect & YES & YES & YES \\
\hline Within- $\mathrm{R}^{2}$ & 0.1002 & 0.2565 & 0.1557 \\
\hline$P$ value of $F$ test & 0.0000 & 0.0000 & 0.0000 \\
\hline$P$ value of Hausmantest & 0.0000 & 0.0000 & 0.0000 \\
\hline$N$ & 31240 & 31240 & 28641 \\
\hline
\end{tabular}

Note: $t$ value is in the blank, ${ }^{*} \mathrm{p}<0.1,{ }^{* *} \mathrm{p}<0.05,{ }^{* * *} \mathrm{p}<0.01$.

constant deepening of the division of labor in the city group. With the expansion of industrial production chain and the constant deepening and breaking through of the scope of individual city for division of labor in society, the industrial system configuration inside the city group has been improved and tends to be complete, the complete industrial system enables the formation of a unified element market between the cities in the city group, thus promoting the increase of employment figure of the industry. The coefficient of city group economies of scale is 0.280 , which shows that the regional "diversification economy" has a positive influence on the increasing of employment. On the one hand, the agglomeration of related or different industries in the city group may bring the sharing effect of infrastructure and business services cost. 
For the other control variables included in the estimated equations, the symbol and significance of coefficients shall be consistent in columns 2, 3, and 4 . The increase of intra-region accessibility usually means the improvement of the transportation infrastructure in the region, so as to reduce transportation costs, and to enable the flow of elements to be more quickly and convenient, which is conducive for the urban or regional population agglomeration, and to promote the growth of industrial employment. In addition, in Table 2, the estimated coefficients of the industry average wage, average capital per labor, and population density are significantly negative. The average capital per labor and population density of the industry respectively reflect the labor costs of enterprises and capital intensive degree, the increase of these two factors will reduce the attractiveness of regional enterprises agglomeration, so it has a negative impact on the increase in employment figure.

\section{Conclusions}

City group is a new type of agglomeration. This paper selects the ten city groups with the highest development degree of China, adopts the micro data of manufacturing enterprises, and constructs the agglomeration economic indexes of the city group level, namely the city group economies of scale and city group economies of scope. On the basis of this, this paper examines the impact of agglomeration economy of the city group on employment in China during 1998-2007.

Generally speaking, both the city group economies of scale and city group economies of scope play a significant role in promoting employment. Foremost, as for the city group agglomeration of the same industry, with the expansion of industrial production chain and the constant deepening and breaking through of the scope of individual city for division of labor in society, the industrial system configuration inside the city group has been improved and tends to be complete. In addition, the agglomeration of related or different industries in the city group may bring the sharing effect of infrastructure and business services cost. Economic ties between each city of the city group are closely related to each other, with diverse and complementary industries as well as the constantly optimizing industrial layout, so that the unified urban system incurred can optimize the allocation of factors.

There are a lot of literatures abroad about the relationship between agglomeration economy and the employment, but no unified conclusion so far, and lack of empirical research in China. About China's experience in existing studies, most studies using the provincial or city level data, this approach ignores the role of agglomeration economy of city group. This paper studies the effect of agglomeration economy of city group in regional level on employment, it is a good complement to existing literatures. But in this paper, there are still some shortcomings. On the one hand, because of data availability, this paper use China's industrial enterprise database during 1998-2007, the lack of updated data may cause measurement error of the regression model. On the other hand, maybe there are factors of more importance that can affect the employment; this article 
is not conducting further mining. Employment is the foundation of people's livelihood and its importance is self-evident, the later researchers can do more relevant analysis.

From the empirical results, it can be seen that the agglomeration economy of city group has a significant role in promoting employment. It has a certain basis that the country takes city group as the main form to promote urbanization so as to achieve the development of the city and the promotion of employment. From the actual situation of China, the cities contained in city group generally belong to several different provinces, and differences in region policy will bring some difficulties for the development of city group. Therefore, policy makers should formulate industrial policies in accordance with the actual situation in the region, to coordinate the development of city groups, so as to promote industrial upgrading and regional coordinated development.

\section{References}

[1] Yao, S. (2001) Chinese Urban Agglomeration. China Science and Technology Press, Beijing.

[2] Zhang, X.L. and Li, P.X. (2014) Economic Mechanism of City Group and Competitive Pattern of City Group in China. Exploration and Free Views, 9, 59-63.

[3] Li, X.X. and Miao, C.H. (2010) Nature and Sources of City Group Economy. Urban Problems, 10, 16-22.

[4] Ding, J.J. (2010) City Group Economy, Multi City Groups and Regional Coordinated Development. Economic Geography, 12, 2018-2022.

[5] Fan, J.Y. and Li, F.W. (2011) The Impact of Spatial Agglomeration of the Manufacturing Industry in China: A Review. South China Journal of Economics, 6, 53-66.

[6] Weber, A. (1929) Theory of the Location of Industries. The University of Chicago Press, Chicago. (Translated by Carl J. Friedrich from Weber's 1909 Book)

[7] Glaeser, E., Kallal, H., Scheinkman, J. and Shleifer, A. (1992) Growth in Cities. Journal of Political Economy, 100, 1126-1152. https://doi.org/10.1086/261856

[8] Henderson, J.V., Kuncoro, A. and Turner, M. (1995) Industrial Development in Cities. Journal of Political Economy, 103, 1067-1085. https://doi.org/10.1086/262013

[9] Bradley, R. and Gans, J.S. (1998) Growth in Australian Cities. Economic Record, 74, 266-278. https://doi.org/10.1111/j.1475-4932.1998.tb01923.x

[10] Cainelli, G. and Leoncini, R. (1999) Externalities and Long-Term Local Industrial Development. Some Empirical Evidence from Italy. Revue D'economieindustrielle, 90, 25-39. https://doi.org/10.3406/rei.1999.1762

[11] Combes, P.P. (2000) Economic Structure and Local Growth: France, 1984-1993. Journal of Urban Economics, 47, 329-355. https://doi.org/10.1006/juec.1999.2143

[12] Dekle, R. (2002) Industrial Concentration and Regional Growth: Evidence from the Prefectures. Review of Economics and Statistics, 84, 310-315. https://doi.org/10.1162/003465302317411550

[13] Blien, U. and Suedekum, J. (2005) Local Economic Structure and Industry Development in Germany, 1993-2001. Social Science Electronic Publishing, 15, 1-8.

[14] Van Soest, D.P., Gerking, S.D. and Van Oort, F.G. (2006) Spatial Impacts of Agglomeration Externalities. Journal of Regional Science, 46, 881-899.

https://doi.org/10.1111/j.1467-9787.2006.00488.x 
[15] Cingano, F. and Schivardi, F. (2004) Identifying the Sources of Local Productivity Growth. Journal of the European Economic association, 2, 720-744. https://doi.org/10.1162/1542476041423322

[16] Blanchard, O., Katz, J.L., Hall, F.R. and Eichengreen, B. (1992) Regional Evolutions. Brookings Papers on Economic Activity, 1, 1-75. https://doi.org/10.2307/2534556

[17] Bonaccorsi, A., Piscitello, L. and Rossi, C. (2006) Explaining the Territorial Adoption of New Technology. A Spatial Econometric Approach. Rivista Scienze Regionali, 5, 11-30.

[18] Chen, L.G., Yang, K.Z. and Wu, J. (2006) Localization Economy and Urbanization Economy: An Empirical Study on the Data of Manufacturing Industry in Provinces of China. Inquiry into Economic Issues, 11, 18-25.

[19] Beaudry, C. and Schiffauerova, A. (2009) Who's Right, Marshall or Jacobs? The Localization versus Urbanization Debate. Research Policy, 38, 318-337. https://doi.org/10.1016/j.respol.2008.11.010

[20] McCann, P. and Fingleton, B. (1996) The Regional Agglomeration Impact of Just-in-Time Input Linkages: Evidence from the Scottish Electronics Industry. Scottish Journal of Political Economy, 43, 493-518. https://doi.org/10.1111/j.1467-9485.1996.tb00946.x

[21] Xiong, X.L. (1997) Distinguish the Hierarchy of Scale Economy and Corresponding Countermeasures. Management World, 4, 29-33.

[22] Cecile, B. (2002) Specialization, Diversification and the Growth of Industrial Industries in China. World Economic Papers, 4, 49-62.

[23] Bo, W.G. (2007) Externalities and Industrial Economic Growth: Evidence from Chinese Province. Panel Data, 1, 37-44.

[24] Li, J.Y. and Song, D.Y. (2008) Specialization, Diversification and Urban Agglomeration Economy: An Empirical Study Based on Panel Data of China's Prefecture. Management World, 2, 25-34.

[25] He, C.F. and Feng, H.P. (2009) City Industry Growth in China: Perspectives of Dynamic Externalities and Economic Transition. Geographical Research, 3, 726-737.

[26] Liu X.Y., Zhang X.L. (2010) Agglomeration Economy and Firm Location Choice: Evidence from Prefectural Data of Firms in China. Journal of Finance and Economics, 11, 83-92.

[27] Chen, J.J., Cui, C.M. and Chen, J.J. (2011) Agglomeration Economy, Spatial Continuity and Enterprise Location Choice: An Empirical Study Based on Data of 265 Urban Cities in China. Management World, 6, 63-75.

[28] Zhou, H., Yu, Z.X. and Yang, Z. (2015) Accessibility, Agglomeration and Location of New Enterprises: Micro Evidence from Chinese Manufacturing Industry. China Economic Quarterly, 4, 1393-1416.

[29] Zhang, H., Zhan, Y.B. and Zhou, K. (2007) Cluster, Diversity and Regional Economic Growth: Empirical Research from China's Manufacturing Industry. World Economic Papers, 3, 16-29.

[30] Shi, L.Y. and Liu, X.Y. (2008) Localization Economy Urbanization Economy and Labor Productivity: An Empirical Study on Chinese Four-Digital Manufacturing Industry. South China Journal of Economics, 3, 43-51.

[31] He, C.F. (2011) Specialized Economy, Diversified Economy and Labor Productivity of Chinese Manufacturing Enterprises. Journal of Harbin Institute of Technology Social Sciences Edition, 6, 1-9.

[32] Fan, J.Y., Feng, M. and Li, F.W. (2014) Industrial Agglomeration and Total Factor Productivity of Enterprise. The Journal of World Economy, 5, 51-73. 
[33] Xiao, J.C. and Yuan, Z. (2007) There Will Be Ten City Groups in China. Decision Information, $5,7$.

[34] Jin, Y., Chen, Z. and Lu, M. (2006) Regional Industrial Agglomeration in China: Economic Geography, New Economic Geography and Economic Policy. Economic Research Journal, 4, 79-89.

[35] Zhang, X.L. (2013) China's Regional Economic Transformation and Development of City Group Economy. Academic Monthly, 7, 107-112.

Submit or recommend next manuscript to SCIRP and we will provide best service for you:

Accepting pre-submission inquiries through Email, Facebook, LinkedIn, Twitter, etc. A wide selection of journals (inclusive of 9 subjects, more than 200 journals)

Providing 24-hour high-quality service

User-friendly online submission system

Fair and swift peer-review system

Efficient typesetting and proofreading procedure

Display of the result of downloads and visits, as well as the number of cited articles Maximum dissemination of your research work

Submit your manuscript at: http://papersubmission.scirp.org/

Or contact me@scirp.org 